\title{
Kelainan Mineral Tulang pada Anak dengan Penyakit Ginjal Kronik
}

Hertanti Indah Lestari, Eka Intan Fitriania, Aditiawati, Minerva Riani Kadir

Bagian Ilmu Kesehatan Anak Fakultas Kedokteran Universitas Sriwijaya/RSUP Dr. Mohammad Hoesin, Palembang

Latar belakang. Penderita penyakit ginjal kronis (PGK) berisiko mengalami abnormalitas mineral, sejalan dengan penurunan laju filtrasi glomerulus (LFG) atau peningkatan stadium PGK. Di Palembang, belum ada laporan mengenai penyakit mineral tulang pada anak akibat penyakit ginjal kronik.

Tujuan. Penelitian ini bertujuan mengetahui kejadian penyakit mineral tulang pada anak dengan PGK.

Metode. Penelitian potong lintang untuk mengetahui kejadian penyakit mineral tulang akibat PGK, dengan pemeriksaan kadar hormon paratiroid, kadar vitamin D, serta pemeriksaan densitas tulang. Subyek penelitian dibagi menjadi kelompok 1 (PGK stadium 1-2) dan kelompok 2 (PGK stadium 3-5).

Hasil. Dari 28 subyek penelitian, rerata usia 10,7 tahun, rasio laki-laki dan perempuan, yaitu 2,5:1. Berdasarkan stadium PGK, 14 subyek dengan stadium 1. Rerata kadar hormon paratiroid pada PGK stadium 3-5 secara bermakna lebih tinggi. Subyek dengan PGK stadium 3-5 memiliki risiko 2x lebih besar mengalami hiperparatiroid. Kejadian defisiensi/insufisiensi vitamin D didapatkan pada 23 subyek (82\%). Kejadian defisiensi/insufisiensi vitamin D tidak berbeda bermakna di antara kedua kelompok. Penurunan densitas tulang terjadi pada 8 subyek , 5 di antaranya osteopenia, dan 3 lainnya osteoporosis.

Kesimpulan. Semua anak dengan PGK baik stadium 1-2 maupun 3-5 menunjukkan tanda kelainan mineral tulang secara laboratorium dan/atau densitometri. Sari Pediatri 2020;21(5):282-8

Kata kunci: PGK, CKD-MBD, kelainan mineral tulang, anak

\section{Mineral and Bone Disorder in Children with Chronic Kidney Disease}

Hertanti Indah Lestari, Eka Intan Fitriana, Aditiawati, Minerva Riani Kadir

Background. Children with Chronic Kidney Disease (CKD) are at risk of having mineral and bone disorder (CKD-MBD), in line with a decrease in glomerular filtration rate (LFG). In Palembang, there have been no reports of CKD-MBD in children.

Objective. This study aims to know the prevalence of Mineral and Bone Disorder in children with CKD.

Methods. Cross sectional study among children age 1-18 years with CKD. We measured the level of parathyroid hormone (PTH), vitamin D, calcium and phosphate level, bone density evaluation. The subjects were divided into CKD stage 1-2 (Group 1) and CKD stage 3-5 (Group 2).

Results. Twenty eight subjects were included in the study; the mean age was 10.7 years, with ratio of male to female was 2.5 . Based on the CKD stage, 14 subjects had CKD stage 1. The mean PTH level and the risk of hyperparathyroidism were significantly higher in children with CKD stage 3-5. Vitamin D deficiency/insufficiency was found in 23 subjects (82\%). The proportion of vitamin D deficiency/insufficiency was not different in both groups. Low bone density was found in 8 subjects, five were osteopenia Conclusion. All children have bone and mineral disorders shown in the laboratory results and/or bone density evaluation. Sari Pediatri 2020;21(5):282-8

Keywords: CKD, CKD-MBD, mineral and bone disorder, children

Alamat korespondensi: Hertanti Indah Lestari. Departemen Ilmu Kesehatan Anak Fakultas Kedokteran UNSRI, Jl. Jenderal Sudirman Km 3.5, Palembang 30126.. Email: hertantilestari@unsri.ac.id 


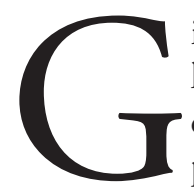

injal memegang peranan penting dalam homeostasis mineral dan tulang dengan cara mengatur metabolisme kalsium, phospor, hormon paratiroid, dan vitamin D. ${ }^{1}$ Pada penyakit ginjal kronis (PGK), gangguan pengaturan metabolisme mineral mulai terjadi sejak stadium awal penyakit, kemudian berlanjut, dan akan menyebabkan perubahan bone modelling, remodeling, dan pertumbuhan. ${ }^{2}$ Kidney disease improving global outcome (KDIGO) membuat terminologi untuk kelainan sistemik akibat abnormalitas metabolisme mineral dan tulang akibat komplikasi PGK yang dikenal dengan istilah chronic kidney disease mineral bone disorder (CKD-MBD) atau diterjemahkan sebagai "kelainan mineral tulang akibat penyakit ginjal kronik"., 3

Manifestasi klinis CKD-MBD sering muncul sebagai gejala nyeri tulang yang tidak spesifik dan sulit dibedakan dari nyeri karena sebab lain sehingga seringkali tidak dikenali. Gejala awal berupa nyeri yang tidak spesifik ini membuat kasus CKD-MBD mungkin tidak terdiagnosis dini oleh klinisi. Diagnosis seringkali baru dapat ditegakkan saat keluhan sudah semakin berat seperti berjalan pincang, keterbatasan gerak dan tidak mampu berjalan sama sekali atau bila anak mengalami fraktur akibat osteoporosis. ${ }^{1}$

Penderita PGK berisiko untuk mengalami abnormalitas mineral saat LFG mencapai $40-70 \mathrm{ml} /$ $\mathrm{min} / \mathrm{m}^{2}$. Suatu penelitian terhadap 52 anak dengan PGK melaporkan bahwa terjadi abnormalitas mineral pada $29 \%$ pasien dengan PGK stage 2, pada $42 \%$ pasien dengan PGK stage 3 dan $79 \%$ pada pasien dengan PGK stage 4/5.,5,6

Risiko untuk terjadinya kelainan mineral tulang ini menjadi salah satu fokus perhatian dalam penatalaksaan pasien PGK. Diagnosis dini dan tatalaksana gangguan metabolisme mineral dan tulang sangat penting dalam meningkatkan kualitas hidup pasien PGK., ${ }^{5}$ Tujuan penelitian ini adalah mengetahui kejadian gangguan mineral tulang pada anak dengan PGK, berdasarkan pemeriksaan kadar hormon paratiroid, kadar vitamin $\mathrm{D}$, serta pemeriksaan densitas tulang?

\section{Metode}

Penelitian ini merupakan studi pendahuluan dengan disain potong lintang yang mengetahui "penyakit mineral tulang akibat penyakit ginjal kronik pada anak dengan penyakit ginjal kronik". Penelitian dilakukan di bagian Ilmu Kesehatan Anak RS Muhammad Hoesin/ FK Unsri Palembang, selama periode waktu Juli 2018 sampai Februari 2019. Subyek penelitian adalah populasi terjangkau yang datang ke bagian Anak RSMH Palembang pada periode waktu penelitian yang memenuhi kriteria penelitian anak usia 1-18 tahun dengan diagnosis Penyakit Ginjal Kronik menurut kriteria NKF-K/DOQI. ${ }^{1}$ Kriteria ekslusi jika terdapat infeksi berat seperti pyelonefritis dan sepsis, penderita penyakit metabolik seperti diabetes mellitus, atau keganasan.

Pasien yang memenuhi kriteria penelitian dimasukkan sebagai subyek penelitian dan dibagi berdasarkan stadium PGK menjadi 2 kelompok, yaitu kelompok PGK derajat I-II dan kelompok derajat III-V. ${ }^{1}$ Penentuan stadium PGK berdasarkan hasil pemeriksaan kreatinin, dan dihitung laju filtrasi glomerulus (LFG) dengan rumus Schwartz.

Setelah dijelaskan oleh tim penelitian, persetujuan orangtua dinyatakan dengan menandatangani formulir informed consent, dilakukan pengambilan data berupa data sekunder rekam medik, meliputi usia, jenis kelamin, diagnosis penyakit primer, riwayat pengobatan kortikosteroid dan vitamin D sebelumnya. Data primer berupa pengambilan sampel darah sebanyak $10 \mathrm{ml}$ untuk pemeriksaan kadar hormon Paratiroid (iPTH), kadar vitamin D (25-hydroxy vitamin $\mathrm{D}, 25 \mathrm{OH}$ vitamin $\mathrm{D})$, kalsium, dan phospat. Kadar iPTH lebih dari $65 \mathrm{pg} / \mathrm{mL}$ didefinisikan sebagai hiperparatiroidisme. Kadar vitamin D kurang dari 30 $\mathrm{ng} / \mathrm{mL}$ didefinisikan sebagai insufisiensi vitamin $\mathrm{D}$, dan kadar kurang dari $20 \mathrm{ng} / \mathrm{mL}$ didefinisikan sebagai defisiensi vitamin $\mathrm{D}$.

Evaluasi tulang dilakukan dengan alat Bone Mineral Density (BMD) merk mesin Stratos ${ }^{(\mathrm{R})}$. Alat harus dikalibrasi dengan standar dari pabrik. Identitas pasien dimasukkan sebelum pemeriksaan meliputi nama, usia, etnis, berat badan dan tinggi badan. Pada saat pemeriksaan, pasien dalam posisi supinasi dengan sentrasi pada vertebrae lumbal, collum femoris, dan radius ulna. Interpretasi hasil pemeriksaan BMD dilakukan oleh dokter konsultan reumatologi. Parameter yang diukur yaitu z-score. Hasil BMD dikatakan normal jika z-score tidak lebih dari 1 SD di bawah nilai normal dewasa muda. z-score - 1,0 sampai $-2,5$ SD didefinisikan sebagai osteopenia (penurunan massa tulang), dan z-score $>-2,5$ adalah osteoporosis. ${ }^{9}$

Data yang diperoleh dimasukkan ke dalam tabel induk. Data statistik diolah dengan program SPSS 17. 
Data deskriptif disajikan dalam bentuk tabular dan tekstular. Analisis data kontinyu dilakukan dengan T-test. Analisis bivariat dilakukan dengan chi-square test. Nilai kemaknaan yang digunakan yaitu $\mathrm{p}<0,05$.

\section{Hasil}

Selama periode penelitian didapatkan 28 subyek penelitian yang memenuhi kriteria penelitian. Rerata usia adalah 10,7 tahun, dengan rasio laki-laki dan perempuan, yaitu 2,5:1. Distribusi karakteristik subyek penelitian tertera pada Tabel 1 .

Berdasarkan usia onset penyakit, 13 subyek sakit mulai usia $<5$ tahun, dan 15 subyek sakit mulai usia 5 tahun. Berdasarkan lama sakit, 18 subyek menderita penyakit kurang dari 5 tahun, dan 10 menderita penyakit sudah lebih dari 5 tahun. Berdasarkan riwayat pengobatan, subyek bisa mendapat lebih dari satu macam di antara pengobatan tersebut tergantung diagnosis penyakit yang mendasarinya.

Tabel 1. Distribusi karakteristik subyek penelitian $(\mathrm{N}=28)$

\begin{tabular}{lcc}
\hline Karakteristik subyek & $\mathrm{n}$ & $\%$ \\
\hline Usia (tahun) & 3 & 10,7 \\
$3-5$ & 17 & 60,7 \\
$6-11$ & 8 & 28,6 \\
$\geq 12$ & & \\
Diagnosis etiologi & 12 & 42,9 \\
SNRS & 7 & 25,0 \\
GNK & 8 & 28,5 \\
CAKUT & 1 & 3,6 \\
Batu & & \\
Stadium klinis & 14 & 50,0 \\
Stadium 1 & 0 & 0 \\
Stadium 2 & 3 & 10,7 \\
Stadium 3 & 0 & 0 \\
Stadium 4 & 11 & 39,3 \\
Stadium 5 & & \\
Riwayat pengobatan & 11 & 39,3 \\
Kortikosteroid & 13 & 46,4 \\
Imunosupresan & 21 & 75,0 \\
Suplementasi kalsium & 14 & 50,0 \\
Suplementasi vit D & 9 & 32,1 \\
$\quad$ Dialisis &
\end{tabular}

Keterangan: SNRS, Sindrom nefrotik resisten steroid;

CAKUT, Congenital anomalies of the kidney and urinary tract; CGN, Chronic glomerulonephritis
Kelompok penelitian selanjutnya dibagi berdasarkan menjadi kelompok 1 (PGK stadium 1-2) dan kelompok 2 (PGK stadium 3-5) masing-masing 14 orang. Distribusi karakteristik subyek berdasarkan stadium klinis tertera pada Tabel 2. Subyek yang berusia 12 tahun dan lama sakit 5 tahun atau lebih secara bermakna lebih banyak pada kelompok 2, dengan OR berturut-turut 8 (95\% CI 1,2 - 50) dan 23,4 (95\% CI 2,3-235).

Distribusi hasil laboratorium subyek berdasarkan stadium klinis dapat dilihat pada tabel 3. Subyek pada kelompok 2 secara bermakna lebih banyak yang mengalami hipokalsemia dibandingkan pada kelompok 1, dengan OR 22 (95\% CI 3,1 - 157). Begitu pula subyek pada kelompok 2 secara bermakna lebih banyak yang mengalami hiperfosfatemia dibandingkan pada kelompok 1, dengan OR 3,0 (95\% CI 1,6-5,5).

Rerata kadar hormon paratiroid pada subyek penelitian ( $\mathrm{n}=21)$ yaitu $107,53 \mathrm{pg} / \mathrm{mL}$ dengan rentang terendah $4 \mathrm{pg} / \mathrm{mL}$ sampai tertinggi $483 \mathrm{~mL}$. Rerata kadar hormon paratiroid pada anak dengan PGK stadium 3-5 adalah 165,69 pg/mL, secara bermakna lebih tinggi dibandingkan PGK stadium 1-2 yaitu $13,01 \mathrm{pg} / \mathrm{mL}$. Beda rerata tersebut secara statistik bermakna, dengan nilai $\mathrm{p}=0,037$.

Tujuh dari 21 subyek $(33,3 \%)$ yang diperiksa hormon paratiroid mengalami hiperparatiroidisme. Subyek pada kelompok 2 secara bermakna lebih banyak yang mengalami hiperparatiroid dibandingkan pada kelompok 1, dengan OR 2,1 (95\% CI 1,25 - 3,68). Artinya subyek dengan PGK stadium 3-5

Tabel 2. Distribusi subyek berdasarkan kelompok stadium klinis $(\mathrm{N}=28)$

\begin{tabular}{lccc}
\hline Karakteristik & Kelompok 1 & Kelompok 2 & $\mathrm{p}$ \\
\hline Jenis kelamin & & & \\
$\quad$ Laki-laki & 9 & 11 & 0,339 \\
$\quad$ Perempuan & 5 & 3 & \\
$\begin{array}{l}\text { Usia (tahun) } \\
\quad<12\end{array}$ & 12 & 6 & 0,023 \\
$\quad \geq 12$ & 2 & 8 & \\
$\quad$ Usia onset sakit & & & \\
(tahun) & & & \\
$\quad<5$ & 4 & 9 & 0,064 \\
$\quad 25$ & 10 & 5 & \\
Lama sakit (tahun) & & & \\
$\quad<5$ & 13 & 5 & 0,02 \\
$\geq 5$ & 1 & 9 & \\
\hline
\end{tabular}


memiliki risiko $2 \mathrm{x}$ untuk mengalami hiperparatiroid dibandingkan subyek dengan PGK stadium 1-2.

Rerata kadar vitamin D pada penelitian ini $(\mathrm{n}=28)$ adalah $21,75 \mathrm{ng} / \mathrm{mL}$, dengan nilai terendah $4 \mathrm{ng} / \mathrm{mL}$ dan tertinggi $41 \mathrm{ng} / \mathrm{mL}$. Defisiensi/insufisiensi vitamin D terjadi pada 23 dari 28 subyek pada penelitian ini (82\%). Proporsi subyek yang mengalami defisiensi/ insufisiensi vitamin D pada kelompok 1 dan kelompok 2 tidak berbeda bermakna (13/14 dan 10/14). Begitu pula rerata kadar vitamin $\mathrm{D}$ pada kelompok 1 dan kelompok 2 tidak berbeda bermakna yaitu 20,99 ng/ $\mathrm{mL}$ dan 22,08 ng/mL.

Pada Gambar 1 tertera data mengenai distribusi hasil pemeriksaan densitas tulang (Bone mineral density) pada 15 subyek, yang terdiri dari 11 subyek kelompok 2 dan 4 subyek pada kelompok 1 . Terdapat 8 subyek dengan penurunan densitas tulang, 5 subyek menunjukkan z-score -1 s/d -2,5 yang disebut sebagai osteopenia, dan pada 3 subyek menunjukkan nilai z-score $<-2,5$ yang berarti sudah terjadi osteoporosis. Proporsi subyek yang mengalami penurunan densitas tulang pada kelompok 2 (6 subyek) lebih banyak
Tabel 3. Hasil laboratorium subyek $(\mathrm{n}=28)$

\begin{tabular}{lccc}
\hline Karakteristik & Kelompok 1 & Kelompok 2 & $\mathrm{p}$ \\
\hline Kadar kalsium & & & \\
$\quad$ Hipokalsemia & 3 & 12 & 0,001 \\
$\quad$ Normal & 11 & 2 & \\
Kadar phosphat & & & \\
$\quad$ Hiperphosphatemia & 0 & 7 & 0,003 \\
$\quad$ Normal & 14 & 7 & \\
Kadar vitamin D & & & \\
$\quad$ Defisiensi & 5 & 7 & \\
$\quad$ Insufisiensi & 8 & 3 & 0,139 \\
$\quad$ Normal & 1 & 4 & \\
Kadar iPTH (n=21) & & & \\
$\quad$ Hiperparatiroidisme & 0 & 6 & 0,032 \\
$\quad$ Normal & 8 & 7 & \\
\hline
\end{tabular}

daripada kelompok 1 (2 subyek), tetapi secara statistik tidak bermakna.

Diagnosis kelainan mineral tulang akibat PGK ditegakkan berdasarkan adanya kelainan laboratorium (hipokalsemia, hiperfosfatemia, defisiensi vitamin D,

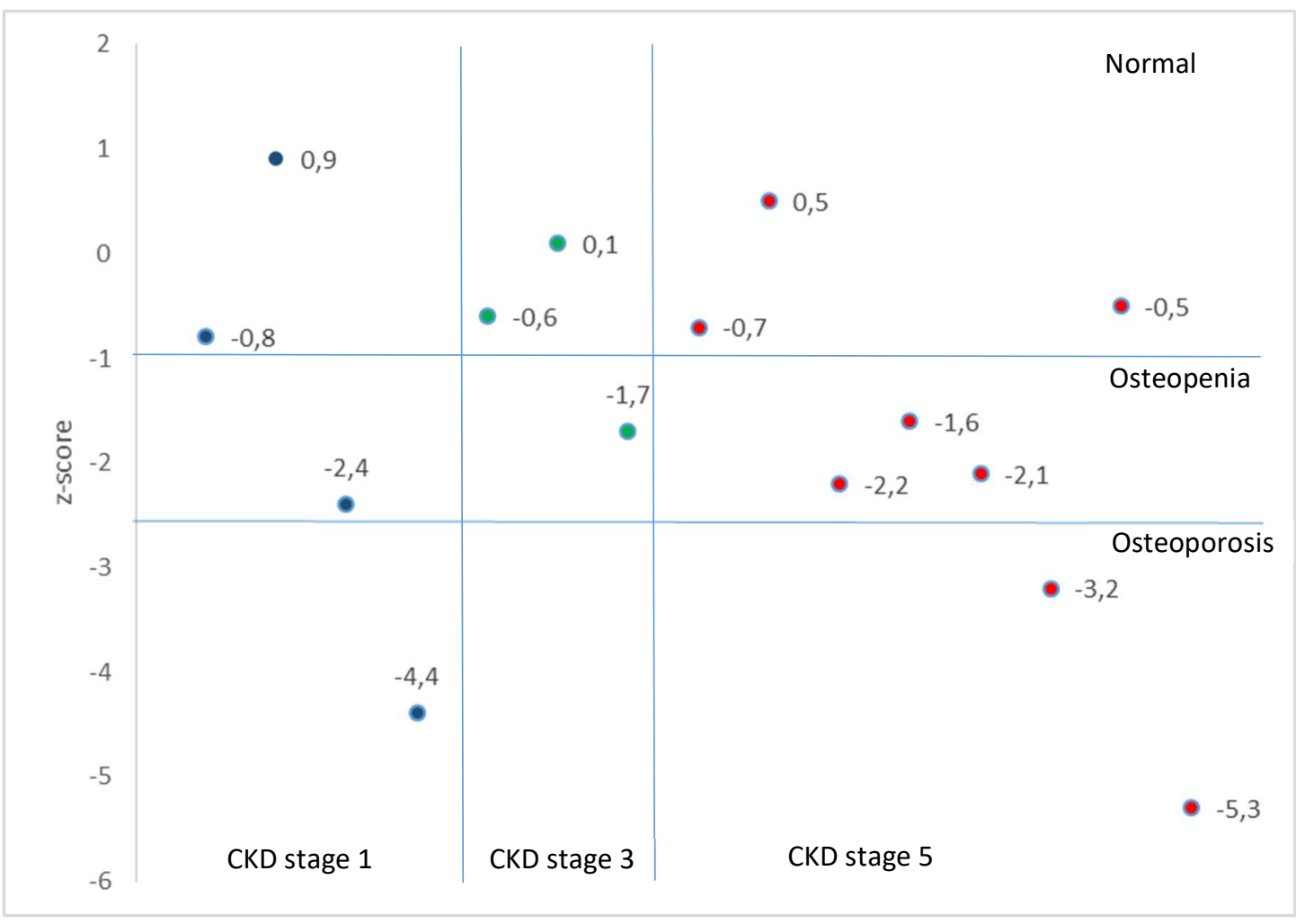

Gambar 1. Distribusi hasil densitometri (z-score) berdasarkan stadium PGK ( $\mathrm{n}=15)$ 


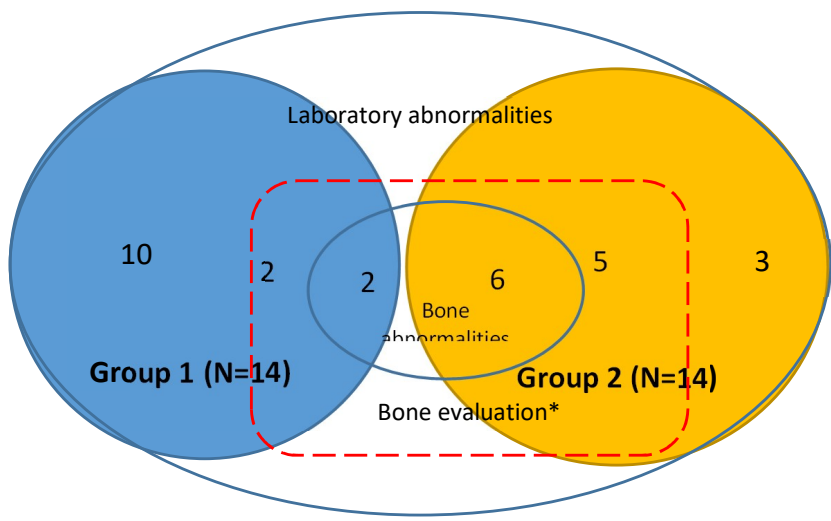

Note: -----

*bone density evaluation performed in 15 subjects.

Gambar 2. Proporsi kelainan laboratorium dan kelainan tulang pada kedua kelompok

hiperparatiroidisme), dan/atau berdasarkan kelainan tulang (penurunan densitas tulang). Pada gambar 2 dapat dilihat ilustrasi penegakan diagnosis kelainan mineral tulang berdasarkan laboratorium dan/atau densitas tulang pada kedua kelompok penelitian.

\section{Pembahasan}

Rerata usia subyek penelitian ini adalah 10,7 tahun, dengan usia terendah 5 tahun dan tertinggi 17 tahun. Kelompok usia terbanyak adalah usia $6-11$ tahun $(60,7 \%)$. Jenis kelamin sebagian besar adalah laki-laki $(71,4 \%)$ dengan rasio laki-laki dan perempuan, yaitu 2,5:1. Berdasarkan usia onset penyakit, proporsi subyek yang sakit mulai usia kurang dari 5 tahun dan di atas 5 tahun relatif sama (13 dan 15 subyek). Berdasarkan lama sakit, sebagian besar subyek diketahui menderita PGK kurang dari 5 tahun (64,3\%).

Berdasarkan penyakit yang mendasari, yang paling banyak adalah PGK yang disebabkan oleh penyakit sindrom nefrotik yang resisten terhadap pengobatan kortikosteroid atau disingkat SNRS, yaitu pada 12 subyek (42,9\%). Penyebab berikutnya adalah CAKUT (congenital anomaly of kidney and urinary tract) pada 8 subyek $(28,5 \%)$, dan penyakit glomerulonefritis kronik (GNK) pada 7 subyek (25\%). Hal ini sesuai dengan literatur bahwa penyebab PGK pada anak yang terbanyak adalah penyakit kelainan kongenital ginjal dan saluran kemih dan penyakit pada glomerulus.

Sesuai dengan penyakit yang mendasarinya, subyek pernah mendapat riwayat pengobatan yang bermacam- macam. Tiga belas $(46,4 \%)$ subyek pernah mendapat terapi kortikosteroid dan imunosupresan. Sebanyak 21 (75\%) subyek pernah mendapat suplementasi kalsium, dan 14 (50\%) subyek pernah mendapat terapi vitamin D. Sembilan $(32,1 \%)$ subyek saat ini menjalani dialisis atau termasuk ke dalam PGK stadium terminal. Hasil ini serupa dengan berbagai laporan mengenai riwayat pengobatan pada pasien PGK, antara lain, pengobatan kortikosteroid dan suplementasi vitamin D. ${ }^{5}$

Pada penelitian ini terdapat 14 subyek pada kelompok 1 (PGK stadium 1-2) dan 14 subyek pada kelompok 2 (PGK stadium 3-5). Kelompok 1 semuanya terdiri dari PGK stadium 1, dan kelompok 2 terdiri dari 3 subyek stadium 3, dan 11 subyek stadium 5 .

Pada penelitian ini, subyek yang berusia 12 tahun atau lebih lebih banyak mengalami stadium PGK yang lebih berat (stadium 3-5), dibandingkan subyek yang berusia di bawah 12 tahun. Begitu pula subyek yang sakit selama 5 tahun atau lebih secara bermakna lebih banyak mengalami stadium PGK yang lebih berat (stadium 3-5). Hasil ini menunjukkan terdapat hubungan yang bermakna antara lama menderita sakit dengan stadium penyakit yang lebih berat. Sementara jenis kelamin dan usia onset sakit tidak berhubungan dengan kelompok stadium klinis.

Enam dari 21 subyek yang diperiksa hormon paratiroid mengalami hiperparatiroidisme $(28,6 \%)$. Semuanya adalah subyek pada kelompok 2 . Rerata kadar hormon paratiroid pada anak dengan PGK stadium 3-5 adalah 165,69 pg/mL, secara bermakna lebih tinggi dibandingkan PGK stadium 1-2 yaitu 13,01 pg/mL. 
Subyek pada kelompok 2 secara bermakna lebih banyak yang mengalami hiperparatiroid dibandingkan pada kelompok 1 (OR 2,1). Artinya subyek dengan PGK stadium 3-5 memiliki risiko 2 kali untuk mengalami hiperparatiroid dibandingkan subyek dengan PGK stadium 1-2. Hasil ini sesuai dengan literatur bahwa hiperparatiroid sekunder mulai terjadi ketika terjadi penurunan LFG di bawah $60 \mathrm{ml} / \mathrm{mnt} / 1,73 \mathrm{~m}^{2}$ atau mulai PGK stadium 3. ${ }^{11}$ Penelitian lain yang pernah melaporkan adanya hiperparatiroidisme pada PGK stadium yang lebih awal tidak terjadi pada penelitian ini. $^{6}$

Pada penelitian ini, defisiensi/insufisiensi vitamin D terjadi pada sebagian besar subyek, yaitu pada 23 subyek (82\%). Proporsi subyek yang mengalami defisiensi/ insufisiensi vitamin D tidak berbeda antara kedua kelompok. Hal ini disebabkan peran ginjal pada aktivasi vitamin $\mathrm{D}$ aktif yang sangat penting sehingga defisiensi vitamin D juga dapat terjadi pada kasus PGK walaupun pada stadium awal PGK. Kalkwarf $\mathrm{dkk}^{10}$ melaporkan kejadian defisiensi vitamin D yang tinggi pada anak dengan PGK stadium 2-5 (hampir separuh dari 182 pasien dengan usia 5-21 tahun). Nigwekar ${ }^{11}$ pada ulasannya menyebutkan kejadian defisiensi vitamin D pada populasi PGK dapat mencapai $70-80 \%$, dan dapat mulai terjadi pada PGK stadium 2. Selain penurunan LFG, defisiensi vitamin D pada kasus PGK juga dapat disebabkan oleh bebagai faktor, antara lain, penurunan paparan sinar matahari, gangguan sintesis kolekalsiferol di kulit akibat penyakit ginjal, hiperpigmentasi yang sering terjadi pada PGK lanjut, pembatasan diet, gangguan absorbsi usus akibat uremia, serta proteinuria yang disertai hilangnya vitamin $\mathrm{D}$ binding protein (DBP) sehingga menyebabkan hilangnya metabolit vitamin D. ${ }^{11}$ Penelitian lain ada juga yang menunjukkan kadar vitamin D yang normal pada PGK stadium yang lebih awal. ${ }^{6}$

Walaupun terdapat riwayat suplementasi vitamin D dan kalsium pada sebagian subyek penelitian (75\% dan 50\%), sebagian besar subyek masih mengalami defisiensi/insufisiensi vitamin D dan hipokalsemia. Data mengenai dosis dan sudah berapa lama mendapat suplementasi kalsium dan vitamin D tidak tersedia pada penelitian ini. Namun, panduan terapi lokal yang digunakan umumnya merekomendasikan suplementasi vitamin D hanya pada PGK stadium lanjut. ${ }^{12,13}$

Hasil laboratorium ditunjang dengan pemeriksaan densitas tulang (bone mineral density), yang menunjukkan 8 dari 15 subyek yang diperiksa mengalami penurunan densitas tulang, 6 di antaranya adalah pada subyek dengan stadium penyakit yang lebih berat (stadium 3-5). Terdapat 2 subyek pada PGK stadium yang awal juga telah mengalami penurunan densitas tulang, keduanya memiliki onset sakit di bawah usia 5 tahun. Satu subyek dengan kelainan kongenital ginjal sudah mengalami gangguan ginjal sejak dalam kandungan, dan 1 subyek SNRS yang memiliki riwayat mendapat terapi kortikosteroid jangka panjang. Laporan lain juga menunjukkan penurunan densitas tulang dapat mulai terjadi sejak PGK stadium 2. ${ }^{6,14}$

Dari 8 subyek dengan penurunan densitas tulang, 5 di antaranya dengan $\mathrm{z}$-score $-1 \mathrm{~s} / \mathrm{d}-2,5$ yang disebut sebagai osteopenia, dan 3 lainnya dengan nilai z-score $<-2,5$ yang berarti sudah terjadi osteoporosis. Subyek yang mengalami osteopenia memiliki risiko 4 kali terjadi fraktur dibandingkan dengan subyek dengan BMD normal. Pada subyek dengan osteoporosis, risiko fraktur menjadi lebih besar, yaitu 8 kali dibandingkan subyek dengan BMD normal. Dua dari 3 subyek yang mengalami osteoporosis adalah PGK stadium 5 yang disebabkan oleh hipoplastik ginjal dan glomerulonefritik kronik yang telah menderita penyakit pada usia kurang dari 5 tahun dan lama sakit sudah lebih dari 5 tahun. Satu subyek lainnya adalah penderita sindrom nefrotik resisten steroid yang memiliki riwayat pengobatan kortikosteroid jangka panjang.

Kelainan tulang pada anak dengan PGK dilaporkan dengan berbagai metode evaluasi dan batasan yang berbeda-beda. Bachrach ${ }^{15}$ menggunakan istilah "kurang menurut usia" jika z-score kurang dari -2,0 SD dari nilai yang diharapkan, dan tidak menggunakan istilah osteoporosis atau osteopenia seperti pada dewasa. Denburg ${ }^{16}$ melaporkan dalam bentuk volumetric dari pemeriksaan CortBMD yang dikatakannya sebagai parameter yang lebih baik bagi populasi anak. Metode apapun yang tersedia umumnya dapat digunakan sebagai bagian dari tatalaksana anak dengan PGK.

Semua subyek pada penelitian ini memiliki tanda kelainan mineral tulang secara laboratorium (parameter biokimia), dengan atau tanpa tanda kelainan tulang (penurunan densitas tulang). Keterbatasan penelitian ini adalah pemeriksaan densitas tulang hanya dilakukan pada 15 dari 28 subyek. Hal ini dikarenakan alat pemeriksaan yang rusak sehingga 10 subyek pada kelompok 1 dan 3 subyek di kelompok 2 tidak diperiksa 
Hertanti Indah Lestari dkk: Kelainan mineral tulang pada anak dengan penyakit ginjal kronik

densitas tulang. Sebagian besar subyek yang tidak diperiksa adalah kelompok 1 karena panduan selama ini baru merekomendasikan pemeriksaan BMD pada PGK stadium lanjut. Pemeriksaan BMD rekomendasi KDIGO mulai dari PGK stadium 3 karena umumnya mulai terjadi penurunan densitas tulang. ${ }^{1-4}$ Penelitian ini juga tidak memeriksa kalsifikasi pembuluh darah dan jaringan lunak yang juga merupakan parameter kelainan mineral tulang pada PGK.

Penegakan diagnosis kelainan mineral tulang pada anak dengan PGK memerlukan pemeriksaan laboratorium dan pemeriksaan tulang yang bukan merupakan pemeriksaan rutin dan tidak selalu tersedia di laboratorium klinik di rumah sakit. Diperlukan kewaspadaan untuk mengenali risiko kelainan mineral tulang pada anak dengan PGK sehingga dapat dilakukan pemeriksaan dan tatalaksana yang optimal untuk mempertahankan kualitas hidup anak dengan PGK.

\section{Kesimpulan}

Semua subyek penelitian menunjukkan tanda kelainan mineral tulang baik secara laboratorium dan/atau densitometri. Hampir sepertiga yang diperiksa hormon paratiroid mengalami hiperparatiroidisme, dan semuanya adalah subyek dengan PGK stadium 3-5. Anak dengan PGK stadium 3-5 memiliki kemungkinan $2 x$ lebih besar untuk mengalami hiperparatiroid dibandingkan pada PGK stadium 1-2. Defisiensi/insufisiensi vitamin D didapati pada sebagian besar subyek penelitian. Penurunan densitas tulang terjadi pada separuh subyek yang diperiksa densitas tulang, dan sebagian besar di antaranya adalah subyek dengan PGK stadium 3-5.

\section{Daftar pustaka}

1. Warady Bradley A, Chadha Vimal. Chronic kidney disease in children: The global perspective. Pediatr Nephrol J 2007;22:1999-2009.

2. Wesseling-Perry K, Salusky IB. Chronic Kidney Disease Mineral and Bone Disorder. In: Avner ED, Harmon WE, Niaudet P, editors. Pediatric Nephrology. Berlin: Springer; 2009.h.1629-755.

3. Ketteler M, Elder GJ, Evenepoel P, Ix JH, Jamal SA, Lafage-
Proust MH, dkk. Revisiting KDIGO clinical practice guideline on chronic kidney disease-mineral and bone disorder. Kidney Int 2015;87:502-8.

4. KDIGO. Clinical practice guideline update for the diagnosis, evaluation, prevention, and treatment of CKD-MBD. Kidney Int 2017:7;1-59.

5. Tsampalieros A, Kalkwarf HJ, Wetzsteon RJ, Shults J, Zemel BS, Foster BJ, dkk. Changes in bone structure and the musclebone unit in children with chronic kidney disease. Kidney Int 2013;83:495-502.

6. Wasseling-Perry K, Pereira RC, Tseng CH, Elashoff R, Zaritsky JJ, Yadin O, dkk. Early skletal and biochemical alteration in pediatric chronic kidney disease. Clin J Am Soc Nephrol 2010;7:146-52.

7. Wesseling-Perry K, Salusky IB. Chronic Kidney Disease Mineral and Bone Disorder in Children. Semin Nephrol 2013;33:169-79.

8. Sekarwana Nanan. Chronic kidney disease. Dalam: Unit kerja koordinasi nefrologi ikatan dokter anak Indonesia. Kompendium Nefrologi Anak. Jakarta: Badan Penerbit Ikatan Dokter Anak Indonesia; 2011.h.215-22.

9. Cunningham J, Sprague SM, Cannata-Andia J, Coco M, Cohen-Solal M, Fitzpatrick L, dkk. Osteoporosis in Chronic Kidney Disease. Am J Kidney Dis 2004;43:566-71.

10. Kalkwarf HJ, Denburg MR, Strife CF, Zemel BS, Foerster DL, Wtzsteon RJ, dkk. Vitamin D deficiency is common in children and adolescents with chronic kidney disease. Kidney Int 2012;81:690-7.

11. Nigwekar SU, Tamez H, Thadhani RI. Vitamin D and chronic kidney disease - mineral bone disease (CKD-MBD). Bonekey Rep 2014;3:498.

12. HK Yap, Resontoc, Patil. Mineral and bone disease. Dalam: Children's kidney centre. pediatric nephrology on the go. Singapore: NUH press; 2012.h.45-66.

13. Yap HK. Anemia, renal osteodystrophy, growth failure in chronic renal failure. Dalam: Chiu MC, Yap HK, penyunting. Practical paediatric nephrology an update of current practices. Hongkong: Medcom Ltd; 2005.h.253-61.

14. Malluche HH, Porter DS, Pienkowski D. Evaluating bone quality in patients with chronic kidney disease. Nat Rev Nephrol 2013;9:671-80.

15. Bachrach LK, Sills IN. Clinical report - bone densitometry in children and adolescents. Pediatrics 2011;127:189-94.

16. Denburg MR, Tsampalieros AK, De Boer IH, Shults J, Kalkwarf HJ, Zemel BS, dkk. Mineral metabolism and cortical volumetric bone mineral density in childhood chronic kidney disease. J Clin Endocrinol Metab 2013;98:1930-8. 